\title{
Petrographic characteristics in the central part of Kosovo
}

\author{
Festim Kutllovci ${ }^{1 \otimes(\bullet)}$, Islam Fejza ${ }^{1 * \otimes(0)}$ \\ ${ }^{1}$ University of Mitrovica, Mitrovica, 40000, Kosovo \\ *Corresponding author: islam.feza@umib.net, tel. +38349260649
}

\begin{abstract}
Purpose. This paper aims to provide complete identification of rock types in the Drenas region by detailed description of all types of the rocks found. The authors intended to determine interruption or continuity of all inter-formational boundaries to accurately delineate them on the ground and fully reflect on the 1: 25000 scale map, as well as to identify the nature of contact between rock types and give its detailed description.

Methods. During August, September, October of 2019, the exploration field trips were carried out. Geological survey works focused on the following areas: complete identification of all rock types on the basis of studying their samples, preparation of thin sections for petrographic (only the magmatic rock), chemical and geochemical analysis. Systematic measurement of structural elements was conducted alongside with identification and description of mineral outcrops areas.

Findings. Based on the study of stratigraphic units and geological description of mineral outcrop areas, we identified different types of rocks using petrography microscope preparation and chemical and geochemical analysis. The area of Drenas has the following lithostratigraphic units: gabbro diabase, harzburgite, metasandstone.

Originality. The originality of the study consists in the use of optical microscope for precise identification of rocks. As a result of the research conducted in the exploration area, we have obtained a clear petrographic description of minerals composition, their texture and mineralization, which allows assessing the possibility of the area exploitation. The analyses were completed at the certified laboratory of Geology-Mining Faculty (Polytechnic University of Tirana) and Geosciences Institute.

Practical implications. Petrographic study and chemical analysis led to the conclusion that the research area has Ni mineralization, which is important for the development of mining sector and the community given the environment is preserved and the adequate way of the area exploitation is applied.
\end{abstract}

Keywords: Drenas zone, mineralogical composition, petrography microscope preparation, deformation, tectonic

\section{Introduction}

The Republic of Kosovo is situated in the central part of the Balkan Peninsula. It borders Albania in the southwest, Montenegro in the west, Serbia in the north and east, and North Macedonia in the southeast. The territory extends within longitudes N41050'58' and 43 015'42", and within latitudes E200 01'30" and 21048'02" [1]-[3]. Kosovo covers an area of $10908 \mathrm{~km}^{2}$. It is characterized by an average altitude of $800 \mathrm{~m}$ above sea level, but it has considerable changes in the relief and morphology of terrain (Fig. 1) [4].

For the stratigraphic setting of these deposits in the Drenas zone, the study provides for numerous cartographic [5] and generalizing operations [6], as well as the analysis of drilling 1 (61.5 $\mathrm{m}$ depth), drilling 2 (40 $\mathrm{m}$ depth), drilling 3 (60 m depth), conducted by the Geozavod-Belgrade institutes (1978). The Permo Triassic Formation occupies almost the eastern half of the Drenas zone.

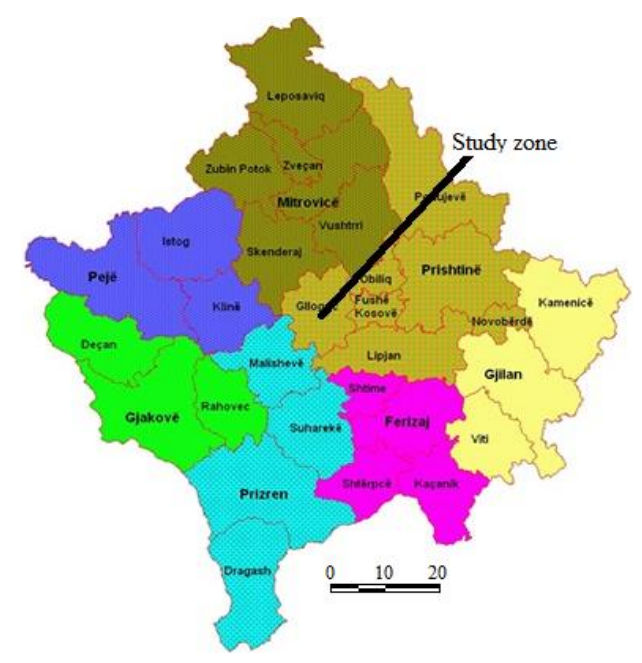

Figure 1. Geographic map of Kosovo (the map prepared by the statistical office)

Received: 9 September 2021. Accepted: 10 December 2021. Available online: 24 December 2021

(C) 2021. F. Kutllovci, I. Fejza

Published by the Dnipro University of Technology on behalf of Mining of Mineral Deposits. ISSN 2415-3443 (Online) | ISSN $2415-3435$ (Print)

This is an Open Access article distributed under the terms of the Creative Commons Attribution License (http://creativecommons.org/licenses/by/4.0/),

which permits unrestricted reuse, distribution, and reproduction in any medium, provided the original work is properly cited. 
We consider this formation as Permo Triassic because of the similarity it has with the formation found in the area of Korab (Fig. 2) in Albania, called "Luma" unit. It also resembles a Permo Triassic formation called "Verrukane", which extends over the Mediterranean region.

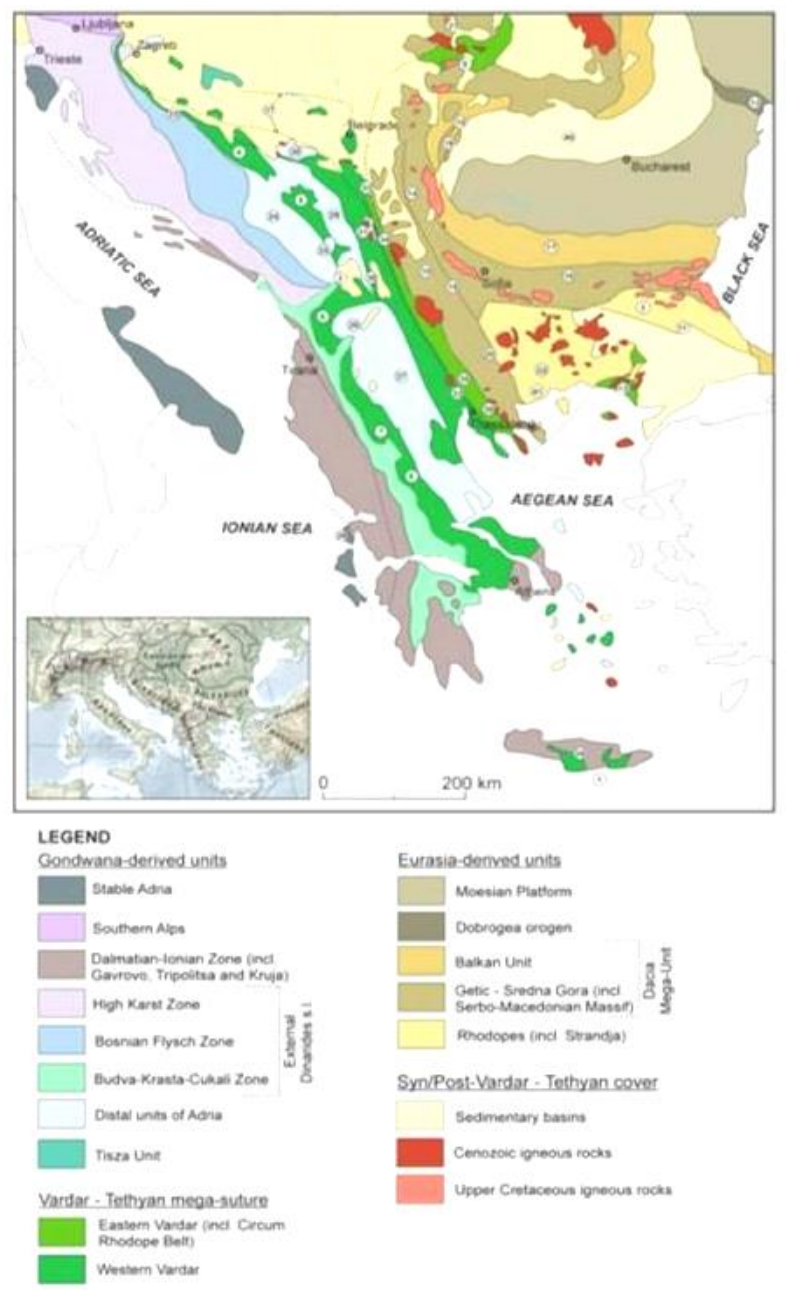

Figure 2. Simplified sketch of the geology of Southeastern Europe

Opinions differ regarding the stratigraphic-tectonic setting and age of these rocks. The authors of the paper [5] think that the rocks of this series belong to the Upper Paleozoic. All this formation occurs on the bottom of the Upper Cretaceous sediments [6]. Based on the data of field observations, it can be concluded that this is a complex, weakly metamorphosed formation, which is located over the Paleozoic schist.

\section{Methods}

During August, September, October of 2019, the exploration field trips were carried out. Geological survey works were focused on the following areas:

1. Complete identification of all rock types represented on the exploration map sheet. Detailed description of rock types according to the model, developed in the days of the general reconnaissance survey. Representative collection of the main rock types indicated in the exploration map sheet.

2. Sampling from all types of rocks to prepare thin sections for petrographic, faunal, chemical and geochemical analysis.

3. Interruption and continuity of all inter-formational boundaries to accurately delineate them on the ground and fully reflect on the 1: 25000 scale map, as well as to identify the nature of contact between rock types and its detailed description.

4. Systematic measurement of structural elements on oriented samples (Fig. 3).

5. Identification and description of mineral outcrop areas.

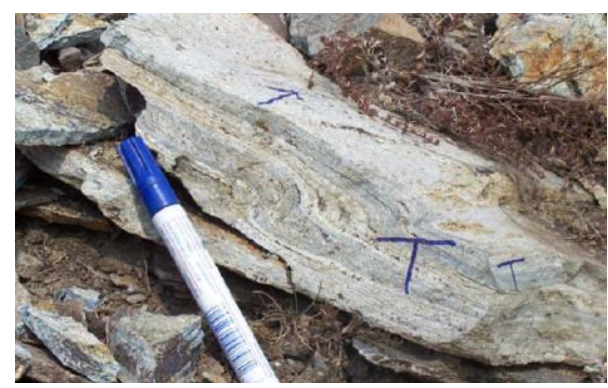

Figure 3. Rock marked with marker for obtaining oriented sample

\section{Results and discussion}

\subsection{Neogen}

Neogene deposits occur in the central and western northwestern area of the Drenas region. They are represented by Lower Pliocene N2n7 and other Pliocene Quaternary deposits N2n8,9-Q. The surface outcropping of these sediments is extremely limited (Fig. 4), which does not allow to perform total correlation of these sediments based on our direct field observations.

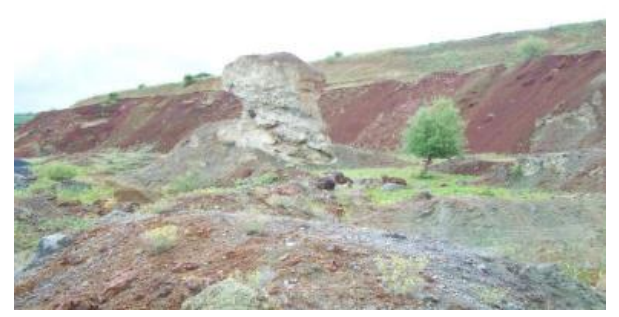

Figure 4. Weathering crust of nickel iron overlying serpentinites

For the stratigraphic setting of these deposits in the Drenas zone, the study provides for numerous cartographic [3] and generalizing operations [7], [8] as well as the analysis of drilling 1 (61.5 $\mathrm{m}$ depth), drilling 2 (40 $\mathrm{m}$ depth), conducted by the Geozavod-Belgrade institutes (Table 1).

In the Drenica region, the Lower Pliocene deposits are transgressively located over the Paleozoic, Triassic, Ultrabasic, Upper Cretaceous formations and over the lateritic crust of nickel silicate. They have a very low thickness and rarely exceed $40 \mathrm{~m}$ in the area of the Drenas zone. The sedimentary series is mainly represented by clays, sands, and gravels, less often by conglomerates and limestones. Gravels, sandy clays with carbonate concretions, and less often sands form the bottom of this series. The coal-bearing horizon is located at the lower and upper boundary of the Lower Pliocene. There is a coal-bearing layer of varying thicknesses with a large or small amount of sterile interlayers (Fig. 5). Numerous materials on these sediments have been generalized in detail by Peca (2003).

Fragments of the Pliocene fauna have been found in the vicinity of Shkaba and Likoshan in small outcrops of gray argillite. In some outcrops in Shkaba, yellowish-white marl clays are observed, which from above turn into gray coal clays, and then into clays with numerous remnants of gastropod fauna. 
Table 1. Drilling in the Drenas exploration area

\begin{tabular}{ccc}
\hline Drilling No. & 1 & 2 \\
\hline Coordinates & $\mathrm{X}-4723679.39$ & $\mathrm{X}-4724008.87$ \\
according to Gauss-Kryger & $\mathrm{Y}-7491159.78$ & $\mathrm{Y}-7491085.61$ \\
& $\mathrm{Z}-659.09$ & $\mathrm{Z}-661.10$ \\
\hline Depth, $\mathrm{m}$ & 61.50 & 10.00 \\
\hline Year of implementation & 1978 & Geozavod-Belgrade \\
\hline Drilling contractor & Geozavod-Belgrade & $0.00-1.00$ Humus \\
Lithological description, & $0.00-1.00$ Humus & $1.00-6.00$ Yellow clay \\
from - to,$(\mathrm{m})$ & $1.00-17.00$ Carbonated serpentinites & $6.00-18.00$ Gray sandstone clay \\
& $17.00-24.00$ Cretaceous limestone & $18.00-36.00$ Dark gray sandstone clay \\
& $24.00-37.00$ Iron Sands & $36.00-40.00$ Limestone \\
\hline
\end{tabular}

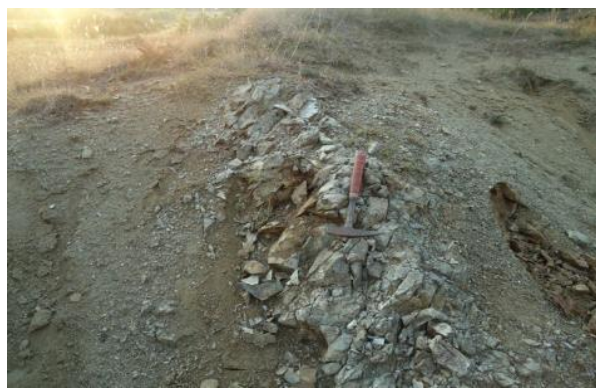

Figure 5. Dacite rock dike in isotropic gabbro

Taking into account the species of Viviparus stracturatus found in the clay sediments of the village of Polac, the zancleane age of the Pliocene sediments has been documented in this region.

\subsection{Middle, upper Pliocene - Quaternary (N2n8, N9-q)}

From the lithological point of view, the sediments of the Middle-Upper Pliocene are similar to those of the Lower Pliocene. The differences are only in the faunal aspect, since there is no fauna in the Lower Pliocene. Their thickness is variable, but does not exceed 30 meters.

The last phase of formation in the Drenica basin is represented by the Quaternary formations. They are formed during the retreat of the lake, and in this case the heaviest material remains at the drying site. They are mainly represented by quartz sand and quartz gravels with different sizes of pebbles, which are often mixed with iron clays.

The oldest Quaternary formations arose in the Pleistocene epoch. Lake formations and river terraces are distinguished.

On the Drenas exploration map sheet, deposits of Pleistocene age cover most of the Neogene relief and a very large area along the Drenica River.

\subsection{Cretaceous $(\mathbf{K})$}

In the northern corner of the central part of the map sheet, around the village of Çikatovë, the influence of the Turonian age on a portion of sediments is limited (K2k2). These Turonian rocks are tectonically in contact with a tectonic wedge of Middle Jurassic serpentinites and with the Triassic limestones. In the southern and southwestern parts, Turonian is covered by the transgression of the Lower Pliocene deposits.

\subsection{0 Jurassic (J)}

In the Drenas zone, Jurassic age formations have limited outcrops to the surface. They are masked by PlioceneQuaternary deposits and are represented by a limited outcrop of supraophiolithic melange precisely in the northeastern corner of the region's zone. The Middle Jurassic ophiolites are represented by serpentinites, outcropped in the northcentral part of the region.

\subsection{Middle Jurassic Supraophiolithic Melange (J2)}

Supraophiolithic melange has previously been termed as volcanogenic-sedimentary formation or diabase-chert complex. In this zone, there is only a limited outcrop of supraophiolytic sedimentary melange. In the western part, it tectonically contacts with marble and marbled limestones of the Middle Triassic, and in the east it is covered with the Lower Pliocene sediments. It presents the base of this melange, where blocks of gabbro, serpentinite, diabase with a matrix represented by metasandstone, clayey shale, etc., are observed.

The Permo-Triassic formation occupies almost the eastern half of the Drenas zone. We consider this formation as Permo-Trasik because of its similarity to the formation found in the Korab area in Albania and called the "Luma" unit. It also resembles a Permo-Triassic formation called the "Verrukane", which is very widespread in the Mediterranean region. Even Peca in (2007) also considers this formation as Permo-Triassic. Tectonically, it contacts with serpentinite and supraphiolite melange of the Middle Jurassic age, as well as with the Turanian carbonate rocks. The tectonic style that controls these collisions is initially the normal tectonic regime that accompanies the continental tectonic detachment. The latter then continues in the style of inverse and normal tectonic faults, acting in the final stages of the alpine restructuring of these geological areas. In the Drenas region, no conclusions have been drawn about the failure of these deposits below the Paleozoic stratum. It is assumed that this contact is as a consequence of the sub-horizontal tectonic detachment, which has recovered the Paleozoic formations from the depths, thus forming Paleozoic nucleus complexes. Both alternatives regarding this contact remain to be verified in other regions where it is clearly expressed. A more or less similar situation is described by Ilic A. and Pesic L. in (2007), where they consider the contact of the dinarides with the Paleozoic as a contact recovering the Paleozoic crystalline nucleus.

Opinions differ on the stratigraphic-tectonic position and age of these rocks. Thus, V. Terzin, A. Mozhina, and R.Antonijevic (1961) believe that the rocks of this series belong to the Upper Paleozoic. But N. Drakulic believes that all this formation occurred on the bottom of the Upper Cretaceous sediments. I. Matijevic, based on the data of field observations, concludes that this is a complex, weakly metamorphosed formation, located over the Paleozoic schist.

Based on 1:100000 compilation of Rahovec, the zones of this formation are divided into two units: the continuous of the Middle and Upper Triassic and the Middle Triassic, documented as conodonts. We have tested the possibility of 
identifying conodonts in some facies of metalimestones not previously identified. But, perhaps due to extreme metamorphism, these fossils have not been identified, the only ones that could help us with more detailed study of this formation.

\subsection{Middle Triassic (T2)}

The formations of the Middle Triassic are divided into two lithological units in which the fauna of the Anisian stage has been found:

- the lower part is made of flaser limestone (calcareous) and marbles;

- the upper part is made of marbled limestone with interlayers of limestone and chlorite schist, as well as limestone breccia.

\subsection{Petrographic characteristics}

Petrographic characteristics in the Drenas region are divided into 6 groups:

1. Harzburgite.

2. Gabbro.

3. Diabase.

4. Metasandstone.

5. Sandstone.

6. Quartzite.

The samples are taken in the exploration area. The mineralogical composition and structure of rocks are tested for Petrographic characteristics using petrography microscope preparation. Figures 6-14 show the samples 1-9 in polarized light. (a)

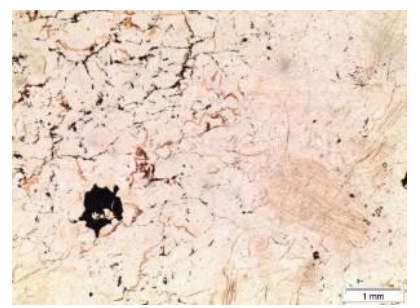

(b)

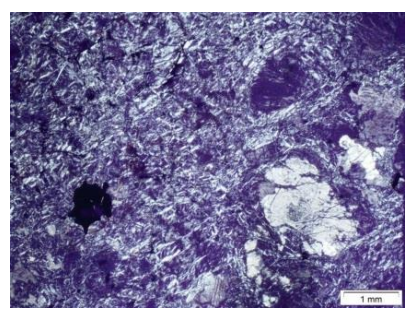

Figure 6. The sample 1 under polarized light: (a) without analysis: (b) with analysis (magnification of 25x)

Harzburgite is serpentinized by relics of orthopyroxene, while olivine is completely altered in serpentine. The rock has a low content of iron oxides. (a)

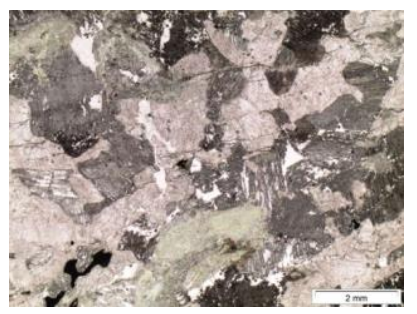

(b)

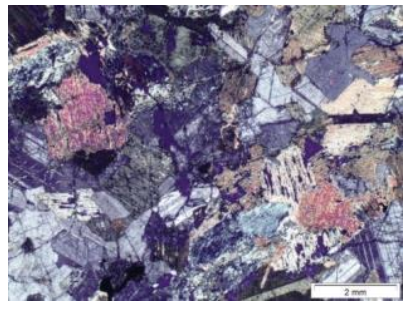

Figure 7. The sample 2 under polarized light: (a) without analysis: (b) with analysis (magnification of 30x)

Gabbro has a granular texture ranging in size from 1 to several $\mathrm{mm}$. The rock is relatively fresh, with a mineralogical composition predominantly of clinopyroxene and plagioclase. Pyroxene is relatively altered, while plagioclase is less transformed into the sericite mineral. An insignificant presence of olivine and opaque minerals is noticed. (a)

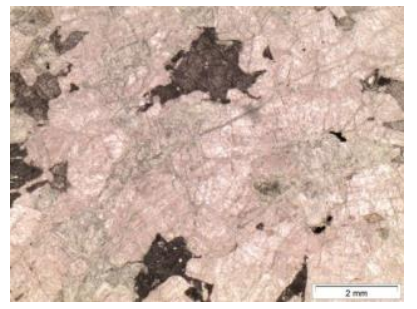

(b)

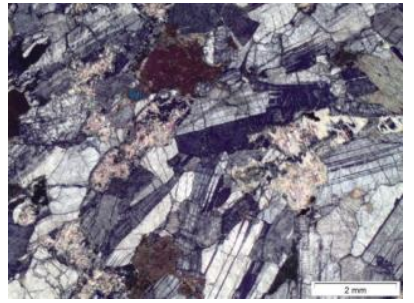

Figure 8. The sample 3 under polarized light: (a) without analysis: (b) with analysis (magnification of $30 x$ )

Gabbro has a granular texture ranging in size from 1 to several $\mathrm{mm}$, with a mineralogical composition predominantly of clinopyroxene and plagio-clase. Most of the rock is mineral plagioclase, while pyroxene is transformed to green amphibole, and then to actinolite with a fibrous structure. (a)

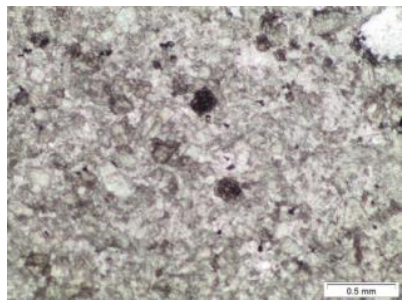

(b)

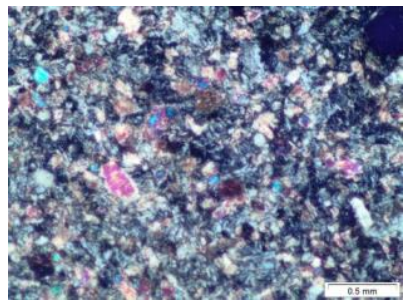

Figure 9. The sample 4 under polarized light: (a) without analysis: (b) with analysis (magnification of $30 x$ )

Diabase with a micro texture of coarse grain from 0.1 to $0.5 \mathrm{~mm}$. The mineralogical composition is dominated by pyroxene, formed earlier, and later crystallization of plagioclase. (a)

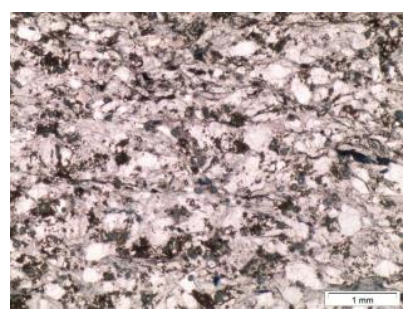

(b)

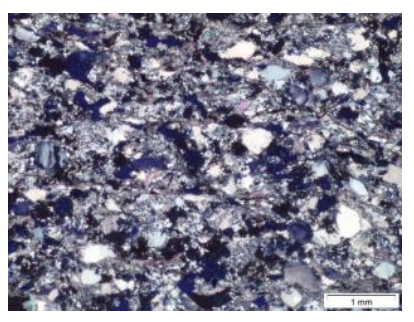

Figure 10. The sample 5 under polarized light: (a) without analysis: (b) with analysis (magnification of $25 x$ )

Metasandstone composed mainly of quartz, which recrystallizes into microcrystals in most of the rock, and represents the extinction of waves. The rock is represented by a highly developed foliation, along which mica minerals are observed. (a)

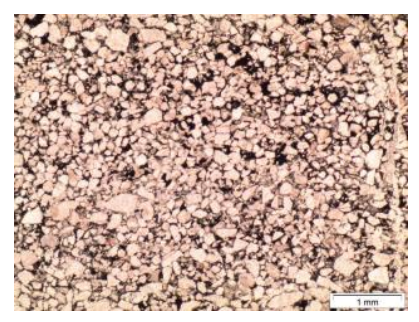

(b)

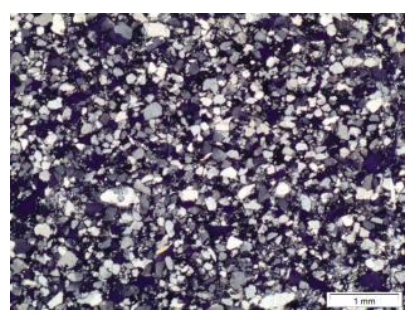

Figure 11. The sample 6 under polarized light: (a) without analysis: (b) with analysis (magnification of 25x) 
Sandstone composed mainly of quartz granules, some feldspar and very little mica. The granule size ranges from 0.1 to $0.5 \mathrm{~mm}$. The rock is represented by a very low degree of metamorphism. (a)

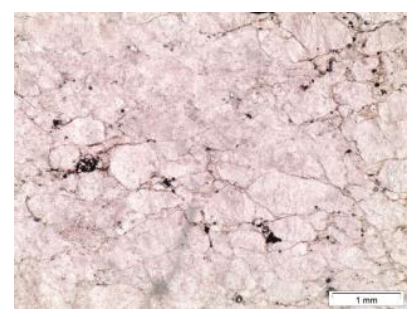

(b)

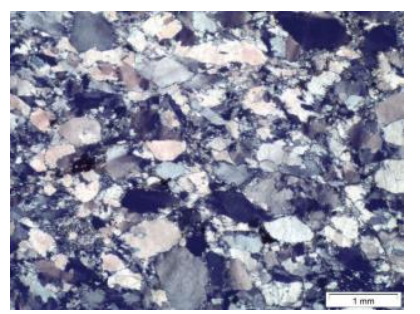

Figure 12. The sample 7 under polarized light: (a) without analysis: (b) with analysis (magnification of $25 x$ )

Metasandstone Sandstone Quartzite composed of almost only quartz with a grain size from 0.5 to $1 \mathrm{~mm}$ and a bimodal distribution of grains. There is another population of micro grains less than $0.1 \mathrm{~mm}$ in size, which forms a matrix of fully recrystallized sandstone. (a)

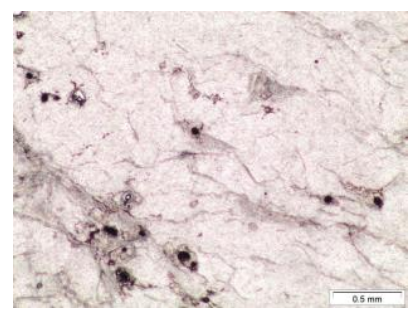

(b)

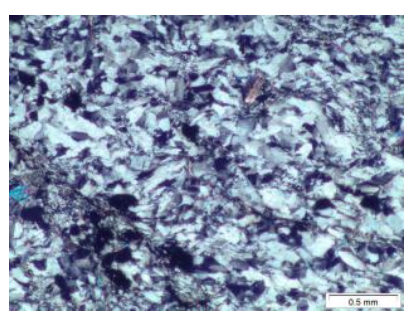

Figure 13. The sample 8 under polarized light: (a) without analysis: (b) with analysis (magnification of 25x)

Metasandstone (quartz), transformed completely into quartz minerals, containing more than $80 \%$ quartz microcrystals ranging in size from 0.01 to $0.3 \mathrm{~mm}$, all recrystallized and very little mica. (a)

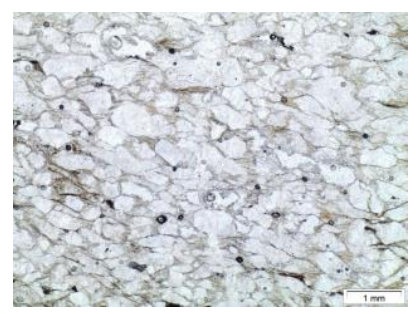

(b)

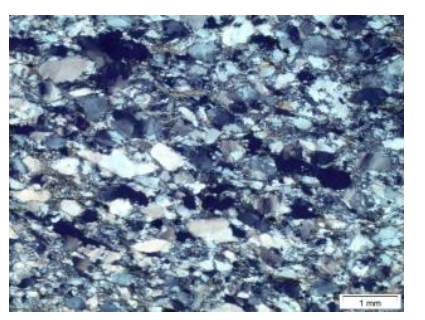

Figure 14. The sample 9 under polarized light: (a) without analysis: (b) with analysis (magnification of 25x)

Metasandstone with a high content of quartz and mica, mostly biotite. The foliation is clearly visible due to the presence of biotite and muscovite minerals. Whereas quartz represents the wave extinction in the most part (especially in the matrix), and recrystallizes into microcrystals.

\section{Conclusions}

Using petrography microscope preparation, the fundamental problems related to geo-structural deformation, tec- tonics, magmatism of mineral resources in the Drenas region, have been revealed. In the part of Drenas, lithostratigraphic units are represented by clays, sand and gravel, less often by conglomerates and limestones. Gravels, sandy clays with carbonate concretions, and less often sands form the bottom of this series, as well as serpentinites, gabbro, diabase, harzburgite, metasandstone.

Based on structural and microstructural analysis, as well as data on the geo-structural background, together with lithochronostratigraphic analysis, four phases of plastic deformation can be distinguished:

The deformation phase during an intra-oceanic fault, recorded in basal peridotites, is further serpentinized, accompanied by the outcrop of ophiolites on the continental crust. A deformation phase is accompanied with the fracture schistosity, in which open folds are not observed or rarely observed on a mesoscopic scale. Their age dating will be the subject of further comprehensive research.

After petrographic results for magmatic rock in the exploration area, we have the following units: gabbro, diabase, harzburgite, followed by Ni mineralization, the lithological units of which have been verified using a petrography microscope preparation, as well as field observations of structural elements.

The tectonic thrust is represented in three directions. The first is of inverse type of the SW-NE direction with a component of horizontal movement, and the second, in the extensional tectonic regime has created the DukagjinDrenica- Kosovo. The latter, which is active even today, has an E-W direction and is an important component of the strike-slip movement.

\section{Acknowledgements}

We would like to express our deep gratitude to Bardhyl Muceku, our professor, or and the entire faculty laboratory staff for their support when conducting microscopic testing of properties and interpreting petrographic characteristic, such as mineral content, structure, texture, and properties of minerals. In addition, we would like to express our gratitude to the Independent Commission for Mines and Minerals for their help in constructing a 1:25000 scale map in Kosovo.

\section{References}

[1] Elezaj, Z., \& Kodra, A. (2007). Gjeologjia e Kosovës. Universiteti i Prishtinës. Kosovë, Prishtinë.

[2] Bulliqi, S., Isufi, F., Ramadani, I., \& Gashi, G. (2012). The relief formed by the descent phenomenon in the north-east part of Kosovo. Journal of Environmental Biology, 33(2), 401.

[3] Rietjens, B. (2016). Providing relief: The case of the Dutch engineers in Kosovo. Managing Civil-Military Cooperation, 111-130. https://doi.org/10.4324/9781315593470-15

[4] Barth, E. (2006). Map of minerals of Kosovo. Available at: https://www.kosovo-mining.org/resurset-minerale/gjeologjia/

[5] Jovanovic, Z. (1974). Facialna obelezija vulkanogeno-sedimentnih tvorevina gornje krede u Dukagjinu-Drenici-Pristina.

[6] Peca, N. (2003). Karakterizimi gjeologjik dhe vlerësimi gjeostatistik $i$ vendburimit të nikelit silikat çikatovë e vjetër - Kosovë. Tirane. $\mathrm{PhD}$ Thesis, $113 \mathrm{p}$.

[7] Terzin, V., Rakic, M., Bodic, D., \& Dimitrievic, M. (1977). Kartu i Tumac za list Vranja. Osnovna Geolloshka Karta 1:100000. Beograd, Serbia.

[8] Karamata, S. (2006). The geological development of the Balkan Peninsula related to the approach, collision and compression of Gondwanan and Eurasian units. Geological Society, London, Special Publications, 260(1), 155-178. https://doi.org/10.1144/gsl.sp.2006.260.01.07 


\section{Петрографічні особливості центральної частини Косово}

\section{Ф. Кутловци, І. Фейза}

Мета. Повне визначення типів гірських порід районі Дренаса шляхом їх докладного опису. Автори мали намір визначити наявність розривних порушень та охарактеризувати суцільність усіх міжпластових меж, щоб точно окреслити їх на місцевості та чітко зобразити на карті масштабу 1:25000, а також виявити специфіку контакту між гірськими породами різного типу та надати його комплексну детальну характеристику.

Методика. У серпні, вересні, жовтні 2019 року були проведені польові геологорозвідувальні роботи, які були зосереджені на наступних напрямках: комплексна ідентифікація всіх типів порід на основі вивчення їх зразків, підготовка шліфів для петрографічного (лише магматична порода), хімічного та геохімічного аналізу. Аналізи були виконані у сертифікованій лабораторії Факультету геології та гірничої справи (Політехнічний університет Тирани) та дослідження проводились в Інституті геологічних наук. Систематичні вимірювання структурних елементів проводилися поряд з виявленням та описом ділянок відслонень корисних копалин.

Результати. На основі вивчення стратонів та геологічного опису ділянок відслонеь діагностовано різні типи порід за допомогою петрографічної мікроскопії та хіміко-геохімічного аналізу. У районі Дренаса представлені наступні літостратиграфічні одиниці: габро діабаз, гарцбургіт, метапісковик. Виділено чотири фази пластичної деформації геологічного району на основі структурного та мікроструктурного аналізу, а також даних щодо геоструктурного фону разом з літохроностратиграфічним аналізом.

Наукова новизна. Новизна дослідження полягає у використанні оптичного мікроскопа для точної діагностики гірських порід. Встановлено чіткий петрографічний опис складу мінералів, їхньої текстури та мінералізації, що дозволяє оцінити можливість експлуатації ділянки.

Практична значимість. Петрографічні дослідження та хімічний аналіз дозволили зробити висновок про те, що у досліджуваній зоні є поклади нікелевих руд, які важливі для розвитку гірничодобувного сектора та суспільства, за умови збереження навколишнього середовища та застосування належного способу експлуатації родовища.

Ключові слова: зона Дренасу, мінералогічний склад, петрографічна мікроскопія, деформація, тектоніка

\section{Петрографические особенности центральной части Косово}

\section{Ф. Кутловци, И. Фейза}

Цель. Полное определение типов горных пород в районе Дренаса путем их подробного описания. Авторы намеревались определить наличие разрывных нарушений и охарактеризовать сплошность всех межпластовых границ, чтобы точно очертить их на местности и четко изобразить на карте масштаба 1:25000, а также выявить специфику контакта между горными породами разного типа и дать его комплексную детальную характеристику.

Методика. В августе, сентябре, октябре 2019 года проведены полевые геологоразведочные работы, которые были сосредоточены на следующих направлениях: комплексная идентификация всех типов пород на основе изучения их образцов, подготовка шлифов для петрографического (только магматическая порода), химического и геохимического анализа. Анализы были выполнены в сертифицированной лаборатории факультета геологии и горного дела (Политехнический университет Тираны), а также исследования проводились в Институте геологических наук. Систематические измерения структурных элементов проводились наряду с выявлением и описанием участков обнажений полезных ископаемых.

Результаты. На основе изучения стратонов и геологического описания участков обнажений диагностировано различные типы пород с помощью петрографической микроскопии и химико-геохимического анализа. В районе Дренаса представлены следующие литостратиграфические единицы: габбро диабаз, гарцбургит, метапесчаник Выделено четыре фазы пластической деформации геологического района на основе структурного и микроструктурного анализа, а также данных о геоструктурном фоне вместе с литохроностратиграфическим анализом.

Научная новизна. Новизна исследования заключается в использовании оптического микроскопа для точной диагностики горных пород. Установлено четкое петрографическое описание состава минералов, их текстуры и минерализации, что позволяет оценить возможность эксплуатации участка.

Практическая значимость. Петрографические исследования и химический анализ позволили сделать вывод о том, что в исследуемой зоне имеются залежи никелевых руд, которые важны для развития горнодобывающего сектора и общества, при условии сохранения окружающей среды и применения надлежащего способа эксплуатации месторождения.

Ключевые слова: зона Дренаса, минералогический состав, петрографическая микроскопия, деформачия, тектоника 